\title{
A Cognitive Semantic Study of selected English and Kurdish Proverbs in the Light of Conceptual Blending Theory
}

\author{
${ }^{1}$ Nyan Kamil Ghafour \\ ${ }^{1}$ Department of English Language, College of Basic Education, University of Halabja, Halabja, Kurdistan Region, Iraq \\ Corresponding author's e-mail: nian.ghafor@uoh.edu.iq
}

\begin{abstract}
Despite of having many proverbs in both English and Kurdish languages with the same image and conveying the same message, there are, at the same time, many proverbs in both languages that convey the same message with different images. This study is an attempt to find such proverbs in both languages to show the similarities that are found and how the Conceptual Blending Theory (CBT) works through analyzing the selected proverbs according to the mental spaces of the theory. The results of analyzing the proverbs according to CB has shown that despite of having differences in context, structure and culture, there are proverbs in different languages with different elements that give the same message. Depending on the analysis of the results, it is concluded that CBT is applicable to the analysis of proverbs in different languages and proverbs are universal phenomenon, with high communicative and instructive power. It is also concluded that there are proverbs in different languages that have the same proposition.
\end{abstract}

Key Words: Cognitive Semantics, Proverbs, Conceptual Blending Theory, Generic Space, Blended Space.

\begin{tabular}{|c|c|}
\hline \multicolumn{2}{|c|}{ 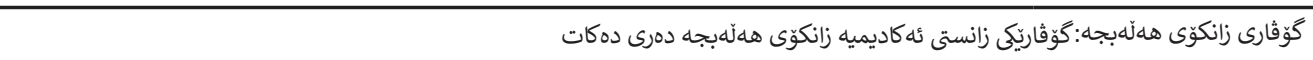 } \\
\hline 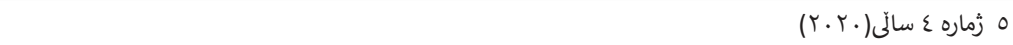 & بهرى \\
\hline 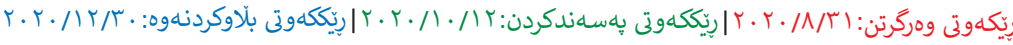 & ريككلكوتهكان \\
\hline nian.ghafor@uoh.edu.iq & تئيمهيلى تويَّهر \\
\hline 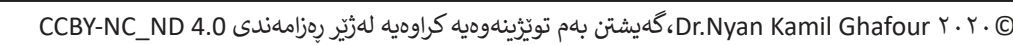 & مافق حابِ و بلاّو كردنهوه \\
\hline
\end{tabular}




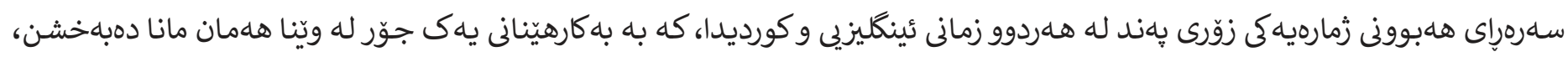

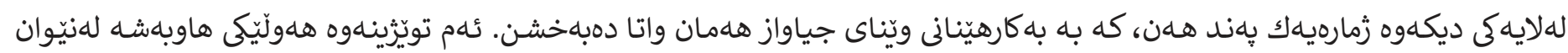

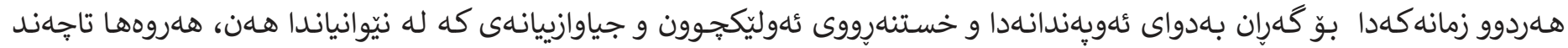

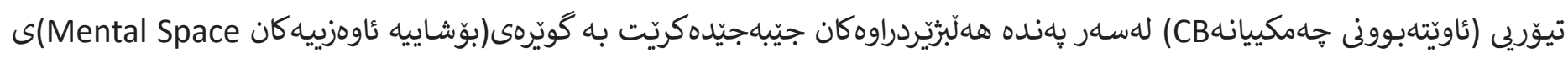

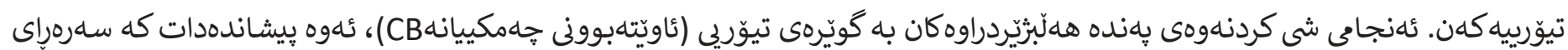

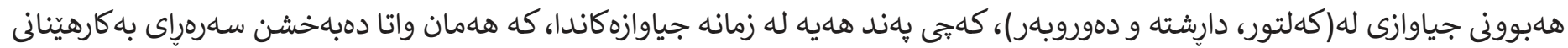

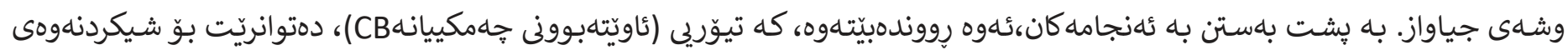

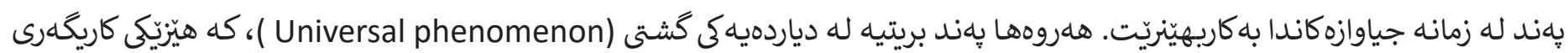

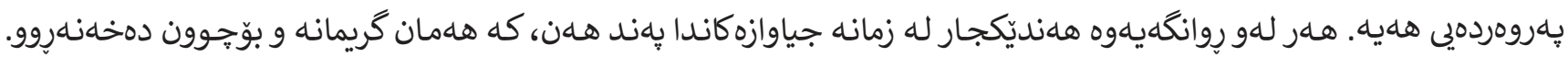

\section{ملخص}

بعض الأمثال في اللغتين الكردية و الإنكليزية تتضمسَّن التصور الذهني و المعنى نفسه ، إلا، أنّ بعضاءمنها تمتلك المعنى نفسه مع التباين في التصور الذهني • و بناء على ما تقدَّم يهدف هذا البحث إلى التقصي عن هذا النوع من الأمثال في اللغتين ، و إيجاد أوجه التشابه و التطابق بينهما ، فضلا=عن إيجاد أثر لعملية الدمج الذهني في بناء المعنى في تلك الأمثال من خلال تحليل لبعض النماذج المختارة ، في ضوء نظرية الدمج الذهني وعلى الرغم من أوجه التباين فيما بين الأمثال المختارة من حيث السياق و التركيب والجانب الثقافي ، إلاسأنّ بعضاءمن تلك الأمثال تضمَّنت المعنى نفسه ، و في ضوء هذه النتائج تبيِّن لنا أنَّ نظرية الدمج الذهني أسهمت في تحليل تلك الأمثال في اللغات المختلفة ، لما للأمثال من أثر تواصلي و توجيهي مؤثر ، كما أظهرت نتائج البحث أنّ الأمثال في لغات مختلفة تمتلك المعنى الدلالي نفسه

\section{Introduction}

Despite the massive literature on proverbs many issues still need to be dealt with and they are in need of being investigated. It is of a great interest to seek if there are different proverbs, with different images in different languages that convey the same message.

This paper is a cognitive semantic study of English and Kurdish proverbs on the light of Conceptual Blending Theory (CBT). It is based on the hypothesis that the conceptual blending theory is applicable to English and Kurdish proverbs and there are also similarities in meaning construction by the uses of different images in proverbs of both languages. The English proverbs are taken from the book ( 101 American English Proverbs) by (Harry Collis 1992). And the Kurdish proverbs from Sheikh Muhammad Khal 1957, pandi peshinan ) as well as from the experience of the researcher as the native speaker of Kurdish language and native specialists of Kurdish Language as well. They assert that most Kurdish proverbs are passed down from generation to generation. 


\section{Conceptual Blending}

Conceptual Blending (CB) is defined as a basic mental operation that leads to new meaning, global insight, and conceptual impressions that are beneficial for memory and manipulation of otherwise diffuse ranges of meaning. It has its role in everyday life and communication and construction of meaning. It has its own role in arts and science as well as behavioral science ( Fauconnier and Turner, 2003)

Yongxiang (2015) regards conceptual integration theory as one of the latest linguistic theories in the western cognitive linguistic field. It also plays a vital role in meaning construction in everyday life, in different fields such as Arts, technology and religious thinking as well.

\section{Proverbs and Their Purposes}

In any language provers are valuable and regarded as a part of folklore or the literature and are also regarded as cultural treasure. They can also be regarded as a means through which one can understand and be familiar with the culture of any nation. A proverb can be a phrase or a sentence that gives an advice or it is a short saying that emerges from the general culture i.e. it is not related to a specific group of people. It is a national heritage. Proverbs are a set of thoughts of different nations that can be short sentences and phrases. Some put proverbs in folklore literature for they are common among the mass of people and are handed down from generation to generation or mostly their origin of most isn't certain. The noticeable point is that most of research which is done about proverbs is limited to gather them up or comparing them among different nations and languages. On the basis of historical texts, Aristotle is the first scholar collecting aphorisms and took scientific research about it, unfortunately his treatise called "aphorisms" was perished. However using proverbs have been common between all of the nations especially civilized nations such as Iran and Greece (Razaei 2012).

Lufti $(2007,296)$ as cited in (Majeed, 2017) states that "proverbs are not just sequences of words, but they are used in real communication as speech acts: they convey a doubt, promise, warning, advice, and make people do something or not.

It can be said that proverbs are not just saying or uttering a phrase or sentence, but they have their own purpose and used by different speakers in different situations for their specific purposes.

\section{The Network Model of Conceptual Blending (CB)}

the network model by Fauconnier and Turner (2003) is explained to clarify what is conceptual blending and its elements as they are shown in figure (1) 
Generic Space

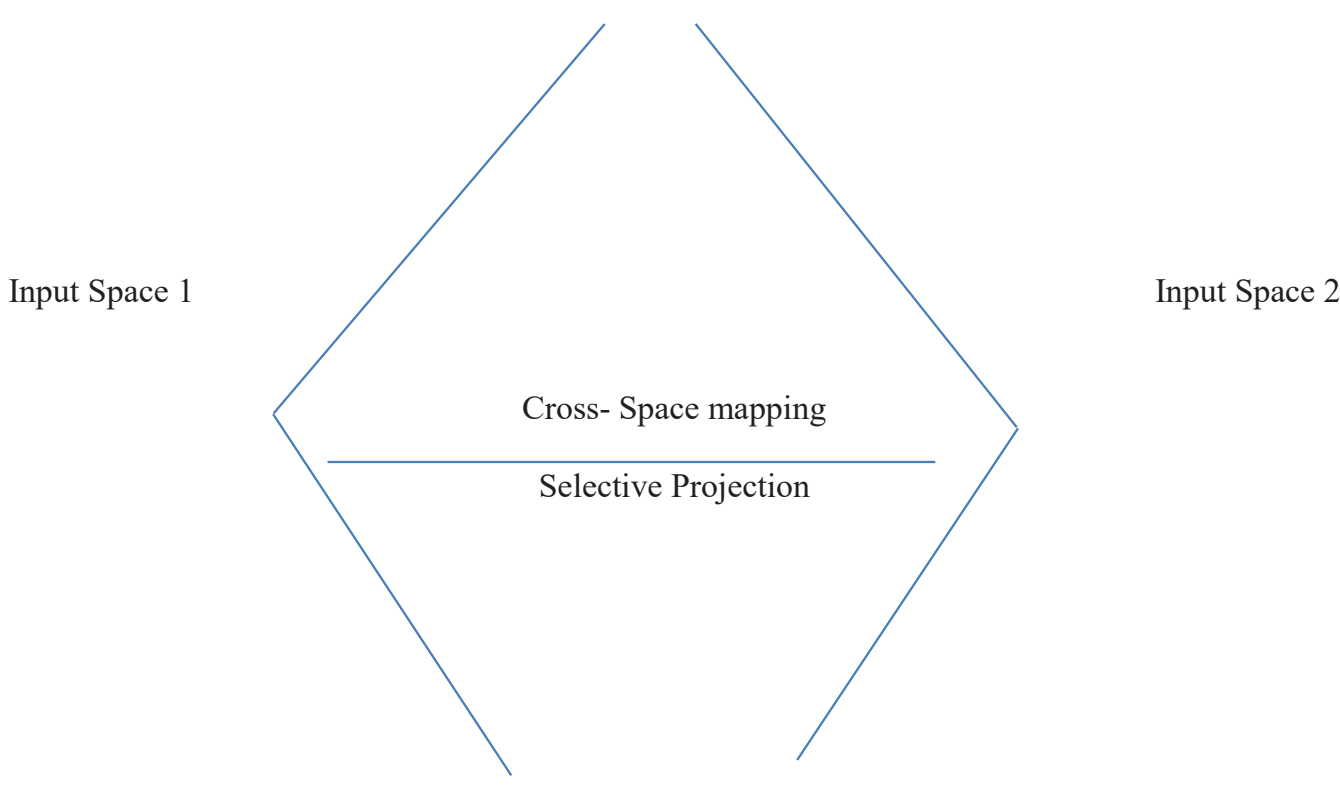

Blended Space

Figure (1) The Conceptual Blending

Figure (1) shows the basic elements of the integration network, Conceptual Blending, which consists of four connected mental spaces, two partially matched input spaces, a generic space which is constituted by structure common to the Inputs, and the blended space. The blended space is constructed through selective projection from the inputs, pattern completion and dynamic elaboration.

The elements of CB that are presented in figure one are explained by (Fauconnier and Turner,1998) and (Croft and Cruse, 2004) as the following:

They define mental spaces as the whole components shown in figure (1) which are the generic structure, the input structures and the blended one. Mental spaces are small conceptual packets constructed as we think and talk, for purposes of local understanding and action. They contain elements which are structured by frames and cognitive models. While generic space maps onto each of the inputs and it refers to what is common between the two inputs. The blended and the third space is projected from the two input mental spaces.

\section{Blending Operations in CB}

Three operations involved in constructing the blend are distinguished by (Fauconnier and Turner, 1998):

\subsection{Composition}


here, in composition, blending composes elements from the input spaces, providing relations that do not exist in the separate inputs. Fusion can be regarded as a kind of composition as the counterparts that may be brought into the blend as separate elements are or as fused elements. As in the boat race example, four different elements are taken from the two Inputs, the two different years 1993 and 1853 as well as the Catamaran and the clipper are brought into the blend.

\subsection{Completion}

Blending recruit a great range of background conceptual structure and knowledge without our recognizing it consciously. This means that the composed structure is completed with other structure. And the completion type is regarded as the fundamental subtype. This indicates that the composition in the blend can be extensively completed by the larger conventional pattern of completion. Again, in the "Boat Race" example, in the blended space we have two boats on the same course, that left the starting point San Francisco on the same day. The completion pattern allows to construe a situation as, a race, by importing the familiar background Frame of racing and the emotions that go with it.

\subsection{Elaboration}

The blend is developed in the Elaboration pattern through imaginative mental simulation according to principles and logic in the blend. Some of these patterns will have been brought into the blend by completion. Continued dynamic completion can recruit new principles and logic during elaboration. New principles may arrive in the elaboration itself. For example the blended message Race in the Boat Race example is created in the final operation, elaboration. It is a new message derived from the inputs of the two events by two different people in two different periods.

\section{Types of CB Network}

The types of CB are mentioned by (Fauconnier and Turner, 2003),(Croft and Cruse, 2004), and (Yangxiang,2015) as the following:

1. Simplex Network

2. Mirror Network

3. Single-Scope Network

4. Double-Scope Network

Yangxiang (2015) exemplifies these networks with reference to some English Proverbs. 


\subsection{Simplex Network}

This type is regarded as the basic and simple conceptual integration network type.

Here, in this network there are two inputs, a generic space and a blended one. The frame is in one input and some elements are in the other one. The blend integrates both in a very simple way. Consider the following English Proverb:

"Failure is the mother of Success".

In this proverb, there are two elements failure \& Success. The relationship is mother and child. In input 1 there is mother kinship mother and child and in In input 2 there are two elements, failure and success. When the proverb is heard or read by someone, $s /$ he integrates failure and success with mother and child in the way that how mother conceives and gives birth to a child, in the same way the abstract concepts failure and success are compared with features of Human being, as failure can also conceive and give birth to success.

\section{2 Mirror Network}

This type is a little more complex than the simplex network. Here, there are four spaces and they all share one organizing frame. Mirror Network is relatively regarded as the standard type of conceptual blending or integration network. The organizing frame provides a set of organizing relations among the elements in the space. The cross-space mapping between the two inputs can easily be put into correspondence as all mental spaces share the same organizing frame.

Here, there are no clashes between the input spaces at the level of organizing frame, what they present, but there may be clashes at the sublevels. It is clarified in the following proverb by Yangxiang :

"Big thunder, little rain.

The concern of this proverb is two sub-events of natural phenomenon, thunder and rain. The literal meaning of the proverb is that 'the force of the rain is much less than what people would expect as compared to the force of the thunder.

Input 1 is, thunder and rain, while Input 2 is a human behavior. As for human's behavior there are two usually related actions in one behavior. The first one precedes the second and typically the magnetic of the first indicates the magnitude of the second which means that when there is big thunder there should be much rain, but in this example the force of the second, little, is much less than people could expect according to the force of the first, big. That's why both inputs have the same organizing frame: two things, sequence general rule and unexpected result.

Here, the types of conceptual blending are carried out. In the blended space some elements from Input 1 are fused with the elements from Input 2. That's the element of, thunder and rain, from mental space of thunderstorm and "two actions" from mental space of human behavior. This is the first step of CB COMPOSITION. The knowledge that magnitude of thunder usually indicates the magnitude of rain according to natural rules. But 
here, there is an unexpected result which is combined with the new condition of human behavior. Here, the second step of COMPLETION is accomplished. And the emergent structure is formed that "there is unexpected result of two things in cause-effect relation, which is the last step ELABORATION of Conceptual Integration.

\section{3 Single- Scope Network}

This type of Network is an extension of the Mirror Network. It has two Input spaces with different organizing frames. Here, in this type, there are two separate organizing frames in the Input Spaces, but only one is projected to the blend as its organizing frame. Since the Input spaces have different frames, there are conceptual clashes in single-scope networks. The single- scope network's features are demonstrated in the following proverb:

"Lawyers, like painters, can easily change white into black."

It is usually rare to consider lawyers as painters. Here, in this proverb there is no difference between lawyers and painters as it is analyzed below:

In the generic space, there is "an agent, material, skill, action, and result". The generic space provides a basis for the cross-space mapping between the two Inputs, and the subsequent selective projection from the Input spaces into the blended space. Some elements in both Inputs have their corresponding with each other, that's the element "painter" is corresponding to "lawyer", "water color" to "proof", "painting skill" to "arguing skill", "painting to "arguing" and "changing color" to "changing adjudge". But two elements in each Input has no corresponding such as "palette, easle" in Input 1 and "Legal costs and Client in Input 2. These are excluded from the subsequent projection. Hence, the new relations are established between the "lawyer" and "painter" and the first step of CB COMPOSITION is completed. Then, these two elements activate the background knowledge and provide some associations which play an important role in completing the COMPLETION step. Usually lawyer is regarded to abide by constitutions and laws, defend for his client, and must stick to the position that cannot be changed as he wishes. The new relations of the first step and the basic knowledge from the second one is projected to the end, here, the third and the last step ELABORATION in the blended space is accomplished in which a "Lawyer" is regarded to be equal to a "painter". The meaning of the proverb is "a lawyer changes his argument from case to case similar to a painter who can do that with the colors he uses.

\section{4 Double - Scope Network}

Fauconnier and Turner (2002) state that Double -scope Network has inputs with different (and often clashing) organizing frames as well as an organizing frame for the blended space from the parts of each of those frames and creates emergent structure of its own. Here, both organizing frames provide elements to the blend, the greater the difference the richer the clashes are going to be and it becomes more creative.

The double-scope network is illustrated in the following proverb: 
"a bad workman always blames his tools"

In this proverb there are two Inputs as each one provides an element for the organizing frame. The first Input the bad workman and Input 2 "blame". In these Inputs such elements indicate that something bad usually happens. One person criticizes or find fault with the other person or something that is responsible for. The elements in the generic space are reason, agent and patient. This makes the cross-space mapping possible, through setting up the relation between the Inputs, the COMPOSITION step of CB is completed. The projection of some of the elements, from the Input spaces and the basic knowledge bring the COMPLETION. In the final ELABORATION step some elements from the Inputs are fused in the blended space as : after failure, the incapable workman criticizes his tools, which he believes is responsible for his failure, rather than his own incapability.

\section{Data Analysis and Results}

In this section, the selected proverbs are analyzed based on the story of the Boat Race as it is a clear example and model to be used for the purpose of comparing two different subjects and bring them into a single one.

\subsection{The Adopted Model}

To arrive at more objective discussion of the proverbs in both languages in the light of Conceptual Blending Theory, the Boat Race story by (Fauconnier and Turner, 2003) is used as the model of the analysis.

\section{"The Boat Race"}

The "Boat Race" is a famous example of blending. The story is as follows:

"A modern catamaran is sailing from San Francisco to Boston in 1993, trying to go faster than a clipper that sailed the same course in 1853". A quotation in a sailing magazine is "As we went to press, Rich Wilson and Bill Biewenga were barely maintaining a 4.5-day lead over the ghost of the clipper Northern Light, whose record run from San Francisco to Boston. In 1853, the clipper made the passage in 76 days, 8 hours." (Great American II Latitude 38, volume 190, April 1993, page 100.)

The story has two different events which are the run by the clipper in 1853, and the run by the Catamaran in 1993 on (approximately) the same course. in the magazine quote, the two runs are merged into a single event which is, a race between the catamaran and the Clipper, "ghost". Despite of having aspects such as the voyage, the departure and arrival points, the period and time of travel, the boat, its position at various times, the two events share a more schematic frame of sailing from San Francisco to Boston, this is the generic space which connects both inputs.

The blending consists of matching the two inputs and projecting selectively from these two input spaces the fourth mental space, the blended space.in the blended space there are two boats on the same course, that left the starting point, San Francisco on the same day. The blended space is a race as the two boats go from San 
Francisco to Boston. The mental spaces of this example are shown in figure (2):

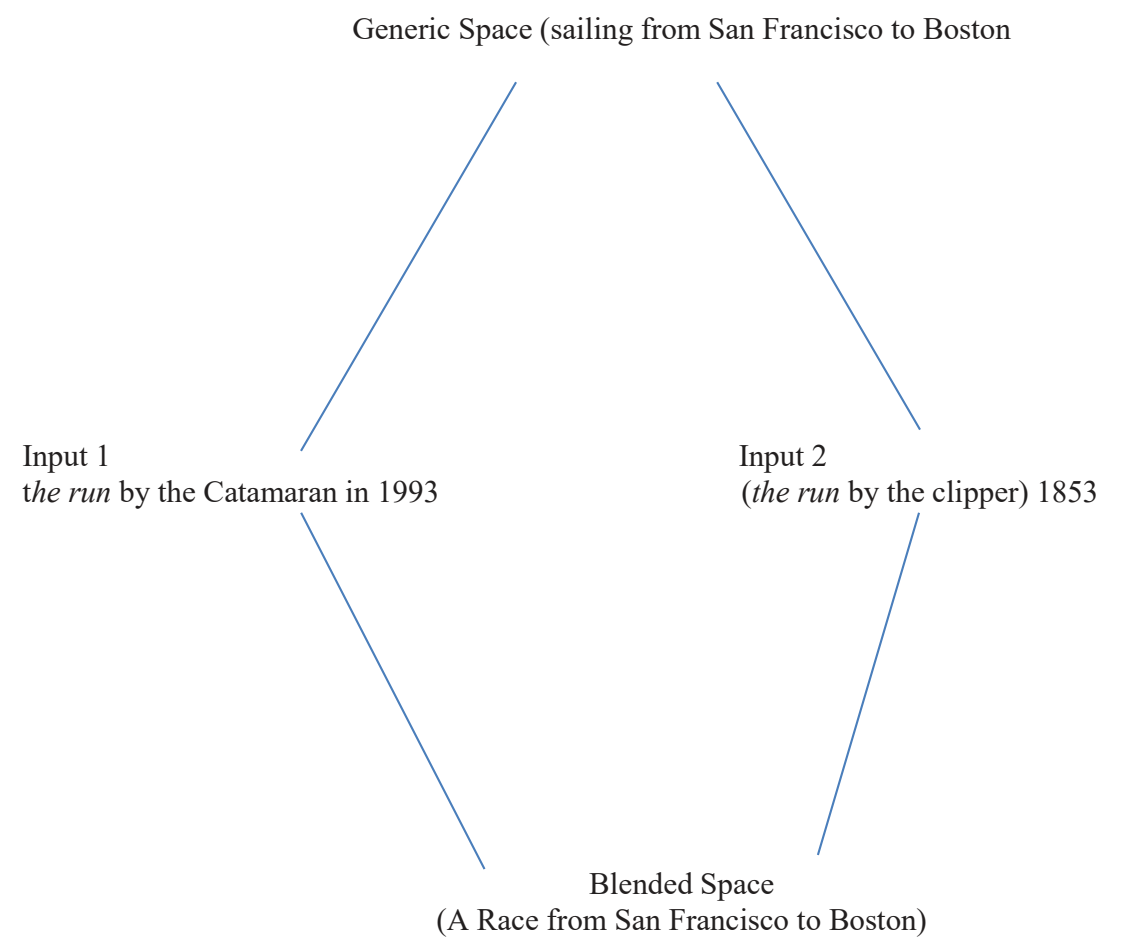

Figure (2)

The Mental Spaces of the "Boat Race" Example.

\subsection{The Analysis of the Selected Proverbs}

In this section, the analysis of the selected English and Kurdish proverbs is carried out. The proverbs in both languages are chosen on the basis that they give the same message but use different images. They are analyzed based on the Conceptual Blending Theory and the model of the analysis the "Boat Race". Here, there are two different events, by two different agents, in two different periods that are combined together according to the conceptual blending theory. The run by two different people, in two different times carry the same purpose of a 'Race'. The same is applied to the selected English and Kurdish proverbs as they are said by different people from different countries, nations and languages with the use of different images but they give the same message or meaning. And proverb in itself carries a message which is different from the meaning of the images or words. It gives a metaphorical meaning as there is a message behind saying the proverb and this is the blended meaning in $\mathrm{CB}$ and the conceptual messages that are given by the syntactic structure of the proverbs as well. The two proverbs are regarded as the two Inputs from which the blended space is formed. 
The Kurdish proverbs with their literal translation and the English equivalent are shown in table (1).

Table (1)

The Kurdish Proverbs, their Literal Translation and English Equivalen

\begin{tabular}{|c|c|c|c|}
\hline No. & Kurdish Proverbs & Literal Translation & English Equivalent \\
\hline 1 & لهئاوى خورِ ملترسه للهئاوى مdنگ & $\begin{array}{l}\text {-Do not be scared of the fast } \\
\text { flowing water, but of the Still } \\
\text { one. }\end{array}$ & - Barking dogs seldom bite. \\
\hline 2 & شايى نازانيّت ده لّيّت عاردهكهى خواره. & $\begin{array}{l}\text {-He does not know how to } \\
\text { dance, yet considers the floor } \\
\text { bumpy. }\end{array}$ & $\begin{array}{l}\text { - A bad workman always blames his } \\
\text { tools. }\end{array}$ \\
\hline 3 & دهنىى دههوّل له دوور خوّشه. & $\begin{array}{l}\text {-The drum sound is sweet when } \\
\text { it is heard at a distance. }\end{array}$ & $\begin{array}{l}\text { - The grass is greener on the other } \\
\text { side of the fence. }\end{array}$ \\
\hline 4 & 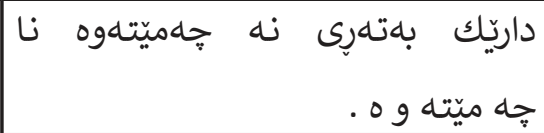 & $\begin{array}{l}\text {-If a wood is not shaped when it } \\
\text { is wet, it cannot be done later. }\end{array}$ & $\begin{array}{l}\text { - You cannot teach an old dog new } \\
\text { tricks. }\end{array}$ \\
\hline 5 & كَيالهسهر بنجى خوّى دمرويت. & $\begin{array}{l}\text {-Grass grows back from its own } \\
\text { root. }\end{array}$ & $\begin{array}{l}\text { - An apple does not fall far from the } \\
\text { tree. }\end{array}$ \\
\hline 6 & فئمِيمهادهانيهى ئاوت ليّخواردهوه بهردى تيّ & $\begin{array}{l}\text {-Do not throw stone in the } \\
\text { headspring water you drank } \\
\text { from. }\end{array}$ & $\begin{array}{l}\text { - Do not bite the hand that feeds } \\
\text { you. }\end{array}$ \\
\hline
\end{tabular}

Here, the analysis is carried out for both the English and Kurdish proverbs similar to what is done in the analysis of the Boat Race story.

\begin{tabular}{|c|c|c|c|}
\hline No. & Kurdish Proverbs & Literal Translation & English Equivalent \\
\hline 1 & لبئاوى خورِ ملترسه للهئاوى مdنگ & $\begin{array}{l}\text {-Do not be scared of the fast } \\
\text { flowing water, but of the Still } \\
\text { one. }\end{array}$ & - Barking dogs seldom bite. \\
\hline
\end{tabular}

In the above couple of proverbs the generic space is constructed from the two inputs. The generic space includes elements like: (fast flowing water, fear of water, barking dogs, fear of bite). These elements correspond to one another. For example, fast flowing water and barking dogs give the same message as they are compared to those people who threaten people with words only but no action. This means that the elements are used metaphorically to mean something different from their literal meaning and this is the main focus of conceptual blending theory. The generic space helps to map across the two inputs and construct a blended space where the projected elements are fused to create new relations. This is the composition process. By creating this relationship between the elements, the completion process is ended. And the final process of elaboration ends with the blended space. The blended message here is: do not be afraid of those people who always try to threaten you by words, they may not hurt you, it is only words, but the silent people may be more dangerous. 


\begin{tabular}{|l|c|c|c|}
\hline No. & Kurdish Proverbs & \multicolumn{1}{|c|}{ Literal Translation } & \multicolumn{1}{c|}{ English Equivalent } \\
\hline 2 & شايى نازانيّت ده ليّت عاردهكى خواره. & $\begin{array}{l}\text {-He does not know how to } \\
\text { dance, yet considers the floor } \\
\text { bumpy. }\end{array}$ & $\begin{array}{l}\text { - A bad workman always blames his } \\
\text { tools. }\end{array}$ \\
\hline
\end{tabular}

The generic space is constructed from the two inputs, the two proverbs, it includes elements like: (bad workman, blame, the tools, bad dancer, the floor, bumpy). These elements correspond to one another, for example, a bad workman corresponds to a dancer who cannot dance very well, he blames his tools and the dancer the floor. The generic space here, helps to map across the two inputs and construct a blended space where the projected elements are fused to create new relations. This is the composition process of CB. By creating this relationship between the elements, the composition process is ended. And the final process of elaboration ends with the blended space. The blended space of the couple of proverbs is, always incapable people have justifications and reasons for their failure or incapability. They always regard something as the cause of their failure not their own incapability.

Here, the type of CB Network is Double-Scope. Fauconnier and Turner ( $Y . Y$ ) state that double-scope Network has inputs with different (and often clashing) organizing frames as well as an organizing frame for the blended space from the parts of each of those frames and creates emergent structure of its own. Here, both organizing frames provide elements to the blend, the greater the difference the richer the clashes are going to be and it becomes more creative. The elements, bad dancer, bad workman, blame the tools, consider the floor bumpy, are all used to create the blend and consider the tools or the floor the cause of their failure not their incapability. And there is a clash between the elements of each input.

\begin{tabular}{|c|c|c|c|}
\hline No. & Kurdish Proverbs & Literal Translation & English Equivalent \\
\hline 3 & دهنكى دمهوّلّ له دوور خوّشه. & $\begin{array}{l}\text {-The drum sound is sweet when } \\
\text { it is heard at a distance. }\end{array}$ & $\begin{array}{l}\text { - The grass is greener on the other } \\
\text { side of the fence. }\end{array}$ \\
\hline
\end{tabular}

The generic space is constructed from the two inputs, the two proverbs, it includes elements like: (grass, green, far, fence, drum, sound, nice, far). Different elements are used in both languages but to give the same message or advice. The above elements in both proverbs correspond to one another, green grass to drum sound. The generic space here, helps to map across the two inputs and construct a blended space where the projected elements are fused to create new relations. This is the composition process of $\mathrm{CB}$. By creating this relationship between the elements, the composition process is ended. And the final process of elaboration ends with the blended space. The blended space is that: always a situation different from your own seems better than yours but this may not be the case. 


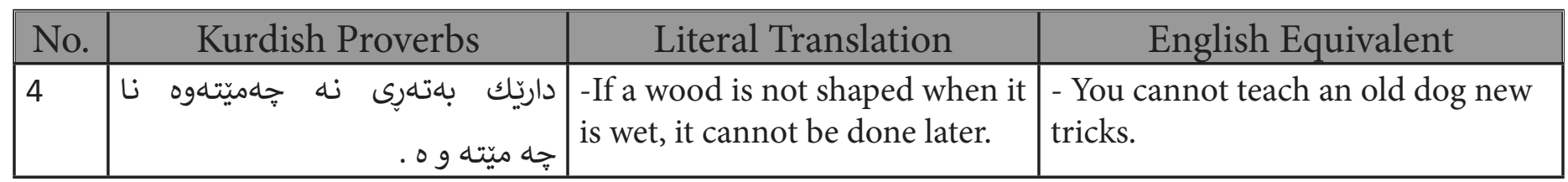

From the inputs of both proverbs the generic space is constructed which include elements like: wood, shaped, wet, old dog, teach, new tricks). The above elements in both proverbs correspond to one another as a wet wood corresponds to a new born dog not an old one. Here, the message of the use of these elements in both languages is to give the message that, you can shape a wet wood as you want but when it gets dry you can do nothing. Similar to a new born dog that you can teach him what and how you want but when it gets old he has already got his own and you cannot teach him new things. Here the generic space helps to map across the two inputs and construct a blended space where the projected elements are fused to create new relations. This is the composition process of $\mathrm{CB}$. By creating this relationship between the elements, the composition process is ended. And the final process of elaboration ends with the blended space.

The blended space here is that: if you want to prepare somebody or something as you want you have to start from the early time, if not you cannot get what you want or planned for.

\begin{tabular}{|l|c|l|l|}
\hline No. & Kurdish Proverbs & \multicolumn{1}{|c|}{ Literal Translation } & \multicolumn{1}{c|}{ English Equivalent } \\
\hline 5 & كيالهسل بنجى خوّى دمرويتي. & $\begin{array}{l}\text {-Grass grows back from its own } \\
\text { root. }\end{array}$ & $\begin{array}{l}\text { - An apple does not fall far from the } \\
\text { tree. }\end{array}$ \\
\hline
\end{tabular}

The generic space is constructed based on the two inputs, what is common between both, the two proverbs are the two inputs. It includes elements like: (grass grow root Apple does not go far tree) These are the elements of both proverbs that are used to give the same message. This generic space helps to map across the two inputs and construct a blended space in which the projected elements are fused to create new relations: grass corresponds to apple, root to the tree. By creating these relations, the composition process is ended. Establishing this relationship or the correspondence between the elements ends the completion process and finally the process of elaboration ends with the blended space, the new idea from both inputs.

The blended space of these two proverbs, the message or the advice they give is : children do not get features of characters quite different from their parents, so parents may not be able to bring up their children in a different way from theirs as they look like them in many aspects.

\begin{tabular}{|c|c|c|c|}
\hline No. & Kurdish Proverbs & Literal Translation & English Equivalent \\
\hline 6 & فئهوكانيهى نئاوت ليّخواردهوه بهردى تيّ & $\begin{array}{l}\text {-Do not throw stone in the } \\
\text { headspring water you drank } \\
\text { from. }\end{array}$ & $\begin{array}{l}\text { - Do not bite the hand that feeds } \\
\text { you. }\end{array}$ \\
\hline
\end{tabular}

Based on the two inputs of both proverbs the generic space is constructed. It includes elements like: (throw stone, headspring, drank, bite, hands, feed) 
the above pairs of elements correspond to one another, and the generic space helps to map across the two inputs and construct a blended space when the projected elements are fused to create new relations. By creatB ing these relations, the composition process is ended. Establishing this relationship or the correspondence between the elements ends the completion process and finally the process of elaboration ends with the blended space, the new idea from both inputs. The blended space from these proverbs is the same advice: do not hurt someone who takes care of you or helps you.

The proverbs $(1,3,4,5$, and 6$)$ are of the Mirror type of CB Network since there are four spaces in each couple of proverbs, and they all share one organizing frame. The organizing frame provides a set of organizing relations among the elements in the space. The cross-space mapping between the two inputs can easily be put into correspondence as all mental spaces share the same organizing frame. the blended space is created from the whole elements of the two inputs when they are fused.

\section{Discussion of Results}

The results of the analysis of the selected English and Kurdish proverbs according to CBT show that despite of having many differences in context, language, structure, environment and the culture of the use of proverbs as well, there are proverbs in both languages with different elements but give the same message.

And in both languages the proverbs are semantically metaphor in the point that they give a message or meaning which is different from their literal meaning.

the applicability of CBT can be seen in the proverbs of both languages as they intend to give a message that should be inferenced from the images used.

Based on the discussion of results, it can be argued that the hypothesis adopted in this research is verified.

\section{Conclusions}

The results of the study lead to the following conclusions:

1. Conceptual Blending Theory is applicable to the analysis of proverbs in different languages.

2. it is concluded that proverbs are a conceptual universal phenomenon, with high communicative and instructive power. As they are used to convey the intended message indirectly and politely.

3. There are proverbs in different languages that have the same proposition.

4. There are proverbs in both Kurdish and English languages that share the same message with different images, the blended space is the same in both languages.

5. The proverbs are metaphorical as they give a meaning which is different from the literal meaning of the words such as advice that is inferenced from the words in a proverb i.e. it is not given directly but it can be 
inferred from the meaning of the words.

6. The processes of $\mathrm{CB}$ are applied to the analysis of the proverbs (Composition, Completion, and Elaboration)

7. different elements are used metaphorically in both languages to give the same message, as fast flowing water and barking dogs which are used metaphorically to describe those people who always try to threaten others, but they take no action.

\section{References}

-Collin's H. (1992) 101 American English Proverbs: Understanding Language and Culture through Commonly Used Saying. Chicago: Contemporary Publishing Group.

-Croft, W. and Cruse, D. A. (2004) Cognitive Linguistics. Cambridge: Cambridge University Press.

-Damien, V. (2014) The Definition of Proverbs and Its Satellites. Presses Academiques Francophones: Sarrebruck.

-Fauconnier, G. and Turner, M. (1998) Conceptual Integration Networks. Cognitive Science Vol22(2) 1998, pp.133-187.Cognitive Science Society, Inc.

-Fauconnier, G. (2001) Conceptual Integration. Emergence and Development of Embodied Cognition.

-Fauconnier, G. and Turner, M. (2002) The Way We Think: Conceptual Blending and The Mind's Hidden Complexities. New York: Basic Books.

-Fauconnier, G. and Turner, M. (2003) Conceptual Blending: Form and Meaning. Recherches en Communication.n. 19.

-Khal, Sh.M. (1957)Pandi Peshinan, Chapi yakam.

-( Khal, Sh.M. (1957) Proverbs: First Edition. Baghdad)

-Lufti, A. (2007) Weather Proverbs and Speech Acts, Joiurnal Of the College of Education.Wasit.Volume 2: pp. 296-304.

-Majeed, S. H. (2017) Speech Acts in Some Kurdish Proverbs and sayings. Zanko Journal For Human Sciences: Salahaddin University. Vol.2, No.2, 2017.

-Razaei, 2012 Rhetorical Function of Proverbs Based on literary Genre. Elsevier Ltd.

-Yongyxiang, Y. (2015) The Explanatory Power of Conceptual Integration Theory for English Proverbs. Studies in Literature and Language. Vol. 11, No.3: 52-56. 